\title{
Differential Expression of Two Vesicular Monoamine Transporters
}

\author{
Doris Peter, ${ }^{1,2}$ Yongjian Liu, ${ }^{2,3}$ Catia Sternini, ${ }^{4}$ Roberto de Giorgio, ${ }^{4}$ Nicholas Brecha, ${ }^{4,5}$ and Robert H. \\ Edwards 2,3 \\ Departments of ${ }^{1}$ Microbiology and Immunology, ${ }^{2}$ Neurology, and ${ }^{3}$ Biological Chemistry, Molecular Biology Institute, \\ UCLA School of Medicine, Los Angeles, California 90024 and ${ }^{4}$ Department of Medicine, CURE: VA/UCLA \\ Gastroenteric Biology Center, and ${ }^{5}$ Department of Anatomy and Cell Biology, UCLA School of Medicine, VA West \\ Los Angeles Medical Center, Los Angeles, California 90073
}

Specific transport proteins package classical neurotransmitters into vesicles so that their release can be regulated by neural activity. Previous studies have suggested that a single activity mediates the vesicular transport of monoamines in the adrenal gland, brain, and other tissues such as mast cells and platelets. However, molecular cloning has recently identified two vesicular transporters for monoamines. Although the predicted proteins are closely related in sequence, they show a range of differences in their physiologic and pharmacologic properties. To clarify further the biological significance of the observed functional differences, we have generated anti-peptide antibodies to the C-termini of the two transporters and used them to determine the distribution and localization of the proteins in the rat. We have detected expression of vesicular monoamine transporter 1 (VMAT1) in adrenal chromaffin cells but not in neural cells. Interestingly, some adrenal chromaffin cells also express VMAT2 but the amount of VMAT2 relative to VMAT1 appears much lower than in the bovine adrenal gland. In contrast, sympathetic ganglion cells express only VMAT2, as do enteric neurons and enterochromaffin-like cells of the stomach. Thus, although adrenal chromaffin cells, sympathetic and enteric neurons derive from the neural crest, they express different vesicular amine transporters. In the CNS, dopamine, norepinephrine, epinephrine, 5-HT, and histamine cell groups all express VMAT2. These findings are consistent with the functional characteristics of VMAT1 and VMAT2 and help to explain several classic pharmacological observations. VMAT2-immunoreactivity is generally stronger in cell bodies, proximal dendrites and axonal processes, indicating the potential for monoamine storage at each of these sites. Surprisingly, dopaminergic interneurons in the olfactory bulb show no detectable immunoreactivity for either VMAT1 or VMAT2.

[Key words: monoamines, vesicular transport, neurotransmitter transport, vesicular monoamine transporter,

\footnotetext{
Received Feb. 27, 1995; revised May 10, 1995; accepted May 16, 1995.

We thank L. Butcher for helpful discussions and Dennis Su for technical assistance. This work was supported by funds from the Public Health Service (MH50712 to R.H.E., DK4301 to C.S., and EY04067 to N.B.), the March of Dimes (R.II.E.) and the American Parkinson's Disease Association (R.II.E.). D. Peter was supported by a fellowship from NIMH.

Correspondence should be addressed to R. H. Edwards, Departments of Neurology and Physiology, UCSF School of Medicine, 3rd and Parnassus Streets, San Francisco, CA 94143-0435.

Copyright $\odot 1995$ Society for Neuroscience $0270-6474 / 95 / 156179-10 \$ 05.00 / 0$
}

synaptic vesicles, sympathetic nervous system, adrenal gland]

The regulated exocytotic release of neurotransmitter in response to neural activity requires storage within intracellular vesicles. For classical transmitters that are synthesized in the cytoplasm or appear there after removal from the synapse by plasma membrane reuplake, storage depends on active transport into the vesicle. Four distinct vesicular transport activities have been identified, one for monoamines, a second for acetylcholine, a third for glutamate, and a fourth for GABA and glycine (Sudhof and Jahn, 1991; Edwards, 1992). Due to the robust activity expressed by bovine chromaffin granules, vesicular amine transport has served as a paradigm for the vesicular transport of neurotransmitters. The chromaffin granule transporter uses the $\mathrm{pH}$ gradient across the vesicle membrane generated by the vacuolar $\mathrm{H}^{+}$-ATPase to drive uptake and so acts as a proton exchanger (Johnson, 1988). In contrast to the plasma membrane transporters for dopamine, norepinephrine and 5-HT which show relative substrate specificity (Amara and Kuhar, 1993), the chromaffin granule transporter recognizes the different monoamine transmitters with roughly similar affinity (Johnson, 1988). The drugs reserpine and tetrabenazine potently inhibit vesicular amine transport and have implicated an analogous transport activity in the storage of monoamines in the CNS (Scherman, 1986). In addition, vesicular amine transport mediates the storage of serotonin by platelets (Fishkes and Rudnick, 1982) and of histamine by mast cells, indicating a role outside the adrenal gland and the nervous system.

Selection in the neurotoxin $N$-methyl-4-phenylpyridinium $\left(\mathrm{MPP}^{+}\right)$has recently led to the molecular cloning of two vesicular monoamine transporters (Liu et al., 1992a). $\mathrm{MPP}^{+}$is the active metabolite of 1 methyl-4-phenyl-1,2,3,6-tetrahydropyridine (MPTP) that produces a syndrome with remarkable clinical and pathological similarity to idiopathic Parkinson's disease (Langston et al., 1983). MPTP selectively injures monoamine neurons because these cells express plasma membrane amine transport activities that accumulate the active metabolite (Javitch et al., 1985). Inside the cell, $\mathrm{MPP}^{+}$enters mitochondria and inhibits respiration (Ramsay and Singer, 1986; Krueger, 1990). The chromaffin granule amine transporter protects the cell by sequestering the toxin in vesicles, away from its primary site of action in mitochondria (Liu et al., 1992a; del Zompo et al., 1993). The amino acid sequence of the transporter predicts twelve transmembrane domains and shows similarity to a class of bacterial antibiotic resistance proteins including the tetracy- 
cline resistance genes from $\mathrm{pBR} 322$ and Tn10 as well as a bacterial multi-drug resistance transporter (Liu et al., 1992b). The ability to protect against $\mathrm{MPP}^{+}$and the apparent evolution from ancient detoxification systems raise the possibility that vesicular amine transport serves two functions in the nervous system, one in packaging transmitter for regulated release and the other in neural protection. Although no exogenous toxin has been identified in the idiopathic disease, the endogenous transmitter dopamine shows considerable toxicity (Rosenberg, 1988; Michel and Hefti, 1990; Cubells et al., 1994) and vesicular amine transport may therefore act to protect against the endogenous transmitter by accumulating it from the cytoplasm.

Northern analysis showed expression of the chromaffin granule transporter in only the adrenal gland (Liu et al., 1992b). A distinct but closely related cDNA has been isolated from a brainstem cDNA library (Liu et al., 1992b) and a basophilic leukemia cell line (Erickson et al., 1992). These two vesicular monoamine transporters differ in terms of their functional properties. The transporter expressed predominantly by the adrenal gland (originally termed chromaffin granule amine transporter, now VMAT1) has an approximately threefold lower affinity for most monoamine substrates than the protein expressed in the CNS (originally termed synaptic vesicle amine transporter, now VM $\Lambda$ T2) (Peter et al., 1994). In addition, VM $\Lambda$ T1 has a lower turnover number than VMAT2. However, the most striking difference in substrate preference by the two transporters concerns histamine: VMAT1 recognizes histamine very poorly whereas VMAT2 recognizes histamine with approximately 100-fold higher affinity (Peter et al., 1994). In terms of pharmacologic sensitivity, tetrabenazine and psychostimulants such as methamphetamine inhibit VMAT2 much more potently than VMAT1 (Peter et al., 1994). Thus, the two transporters show substantial differences in their physiological properties as well as in their pharmacology. To further clarify the significance of these differences in transport activity for neural protection as well as synaptic transmission, we have raised anti-peptide antibodies to the C-termini of both proteins and have determined their distribution and cellular localization.

\section{Materials and Methods}

Peptide synthesis and antibody production. The peptide (C)SYPIGDDEESESD was synthesized manually and coupled through an N-terminal cysteine to keyhole limpet hemocyanin (KLII) using $m$-maleimidobenzoyl $N$-hydroxysuccinimide ester (MBS) (Liu et al., 1994). The conjugated peptide $(250 \mu \mathrm{g})$ was emulsified in Freund's complete adjuvant and injected intradermally into female adult rabbits. Six weeks later, antibody production was boosted with the subcutaneous injection of 100 $\mu \mathrm{g}$ conjugated peptide emulsified in incomplete Freund's adjuvant. Twelve days after the boost, the animals were bled through an ear vein and the antibody titer assessed using a solid-phase ELISA (Liu et al., 1994). Animals producing anti-peptide antibodies were boosted further with $100 \mu \mathrm{g}$ of conjugated peptide at 6 week intervals. The sera were collected 2 weeks after each boost. The anti-peptide antibodies were purified on a peptide affinity column of epoxy-activated sepharose $6 \mathrm{~B}$ (Pharmacia). To demonstrate specificity on Western blots, the antibody was diluted 1:100 in $500 \mu l$ Tween 20/phosphate-buffered saline containing $1 \mathrm{mg}$ peptide and incubated overnight at $4^{\circ} \mathrm{C}$. For immunohistochemistry, the antibody was diluted at $1: 500$ or $1: 1000$ in $0.5 \%$ Triton $\mathrm{X}-100 /$ phosphate buffer with $10^{-5} \mathrm{M}$ peptide and incubated overnight at $4^{\circ} \mathrm{C}$. Peptides used were the same as those used for antibody production.

Western blot analysis. Postnuclear supernatants were prepared from wild-type and transfected CHO cells and approximately $25 \mu \mathrm{g}$ protein separated by electrophoresis through $10 \%$ SDS-polyacrylamide containing $6 \mathrm{M}$ urea. The gels were then transferred to nitrocellulose with a semidry electrotransfer apparatus and the filters probed as described previously (Liu et al., 1994). Briefly, the filters were blocked in phos- phate-buffered saline containing $0.1 \%$ Tween-20 (TBS) and 5\% nonfat dry milk, incubated in TBS containing primary antibody and $1 \%$ nonfat dry milk at a dilution of 1:1000 for $1 \mathrm{hr}$ at room temperature, washed three times in TBS, and incubated with secondary antihody conjugated to peroxidase (Vector) and the immune complexes visualized by chemiluminescence (Amersham).

Tissue preparation. Adult albino Sprague Dawley rats were used for the studies. The animals were housed in a standard environment with free access to food and water. Experimental procedures were consistent with those stipulated in the NIH Guide and approved by the Veterans Administration Animal Research Committee. For brain, spinal cord, superior cervical ganglion, submandibular and adrenal gland, rats were deeply anesthetized with $30 \%$ chloral hydrate and perfused through the heart with $4 \%$ paraformaldehyde (PFA) in $0.1 \mathrm{M}$ phosphate buffer, $\mathrm{pH}$ $7.4(\mathrm{~PB})$. Tissue specimens were postfixed in the same solution for $1-$ $2 \mathrm{hr}$ at room temperature. Following fixation, tissue was stored at $4^{\circ} \mathrm{C}$ in $25 \%$ sucrose/PB. The brain and spinal cord were sectioned with a sliding microtome at $30 \mu \mathrm{m}$ and the sections were stored free-floating in $\mathrm{PB}$ at $4^{\circ} \mathrm{C}$. The superior cervical ganglion, submandibular gland, and adrenal gland were cut with a cryostat at $12-15 \mu \mathrm{m}$, the sections collected onto slides coated with chrom alum and gelatin and stored at $-20^{\circ} \mathrm{C}$. For collection of the gut tissue, rats were anesthetized with halothane and decapitated. The stomach and small intestine were dissected out fresh, pinned onto wax plates, fixed overnight in $4 \%$ PFA/ $\mathrm{PB}$ at $4^{\circ} \mathrm{C}$, and after incubation in $25 \%$ sucrose/PB for $12-24 \mathrm{hr}$, sectioned with a sliding microtome at $30 \mu \mathrm{m}$ and stored in $\mathrm{PB}$ at $4^{\circ} \mathrm{C}$.

Immunohistochemistry. VMAT-1 and VMAT-2 antibodies were used at a final dilution of 1:500 and 1:1000, respectively. Tissue sections were processed for immunohistochemistry using the avidin-biotin peroxidase method (Vector). Briefly, sections were washed in $\mathrm{PB}$, pretreated in $0.1-1 \% \mathrm{H}_{2} \mathrm{O}_{2}$ for $15 \mathrm{~min}$ and incubated in the primary antibody, $10 \%$ normal goat serum, and $0.5 \%$ Triton X-100 in PB for $18-24 \mathrm{hr}$ at $4^{\circ} \mathrm{C}$. The sections were then incubated in biotinylated goat anti-rabbit secondary antibody diluted $1: 100$ in $10 \%$ normal goat serum/PB and Triton X-100, washed and subsequently incubated in an avidin-biotin complex conjugated to horseradish peroxidase. Sections were then washed, incubated in $3^{\prime}, 3^{\prime}$-diaminobenzidine (DAB) with $0.01 \% \mathrm{H}_{2} \mathrm{O}_{2}$ Free floating sections were mounted onto slides coated with gelatin. All of the tissue samples were incubated in $0.5 \%$ osmium tetroxide for 10 sec, dehydrated through graded alcohols, cleared in xylene and coverslipped with Krystalon. The specificity of the stain was assessed by (1) substitution of the primary antibody with nonimmune serum and (2) by preadsorption of the primary antibody with the peptide antigen as described above for antibody production.

\section{Results}

To determine the distribution of vesicular monoamine transporters VMAT1 and VMAT2, we raised polyclonal antibodies to peptides derived from the sequence predicted by the two cDNAs (Liu et al., 1992b). In both cases, peptides derived from the C-terminus of the proteins and coupled through an $\mathrm{N}$-terminal cysteine to $\mathrm{KLH}$ produced antibodies with the highest titer as determined by ELISA. Purification of the sera by affinity chromatography reduced background staining. We have previously reported Western analysis showing that the antiserum to VMAT1 recognizes a protein of $\sim 55 \mathrm{kDa}$ in transfected but not wildtype CHO cells (Liu et al., 1994). Adsorption of the VMAT1 antiserum with the peptide sequence used for antibody production abolished immunoreactivity in tissue sections (Liu et al., 1994). The antibody to VMAT2 similarly recognizes a protein of $\sim 55 \mathrm{kDa}$ in CHO cells transfected with VMAT2, but not wild-type cells (Fig. 1). Higher molecular weight forms are due to glycosylation (Liu et al., 1994; unpublished observations). However, the source of additional immunoreactive bands migrating more rapidly than the strongest VMAT2 band remains unclear. They did not vary with the inclusion of protease inhibitors (data not shown) and did not appear on immunoprecipitation (Y.L. and R.H.E., unpublished observations). A background band of roughly equivalent intensity appears in both transfected and wild-type cells, confirming that similar amounts of protein 


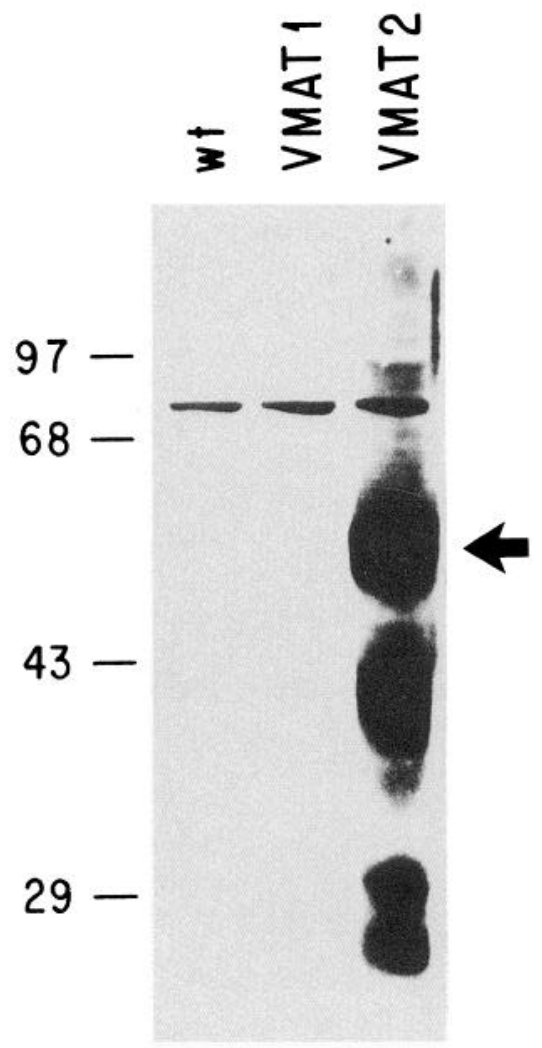

Figure 1. VMAT2 antibody does not recognize VMAT1. Postnuclear supernatants $(\sim 25 \mu \mathrm{g})$ from wild-type $\mathrm{CHO}$ cells and $\mathrm{CHO}$ cells stably transfected with VMAT1 and VMAT2 were separated by electrophoresis through $10 \%$ SDS-polyacrylamide and electroblotted to nitrocellulose. An antibody generated against a C-terminal peptide predicted from the sequence of VMAT2 recognizes a series of bands in cells expressing VMAT2 but not cells expressing VMAT1 or wild-type cells. The predominant species migrates at approximately $55 \mathrm{kDa}$ (arrow) and the other species were not influenced by the presence or absence of protease inhibitors (data not shown). A consistent background band confirms that roughly equal amounts of protein were loaded in each of the three lanes.

were present in each lane. Finally, the VMAT2 antibody does not recognize VMAT1 in transfected cells (Fig. 1). Thus, the VMAT2 antiserum shows both sensitivity and specificity.

\section{Adrenal gland}

Although Northern analysis originally showed expression of VMAT1 but not VMAT2 mRNA transcripts by the rat adrenal gland, in situ hybridization with oligonucleotide probes has suggested that ganglion cells located within the gland express VMAT2 (Mahata et al., 1993). In addition, purification and molecular cloning of an amine transporter from bovine chromaffin granules has indicated a protein with greater similarity to rat VMAT2 than VMAT1 (Stern-Bach et al., 1990, 1992; Krejci et al., 1993; Howell et al., 1994). In previous studies, we found that essentially all adrenal medullary cells in the rat express VMAT1 (Liu et al., 1994), suggesting that the adrenal contains predominantly VMAT1. However, the antibody to VMAT2 also stained some cells in the adrenal medulla. Whereas VMAT1 immunoreactivity is strong in the adrenal medulla and occurs in all chromaffin cells (Fig. $2 B$ ), adjacent sections show that some chromaffin cells also immunostain for VMAT2 (Fig. 2A), indicating that a small proportion of adrenal medullary cells are likely to express both vesicular amine transporters. VMAT2-im-
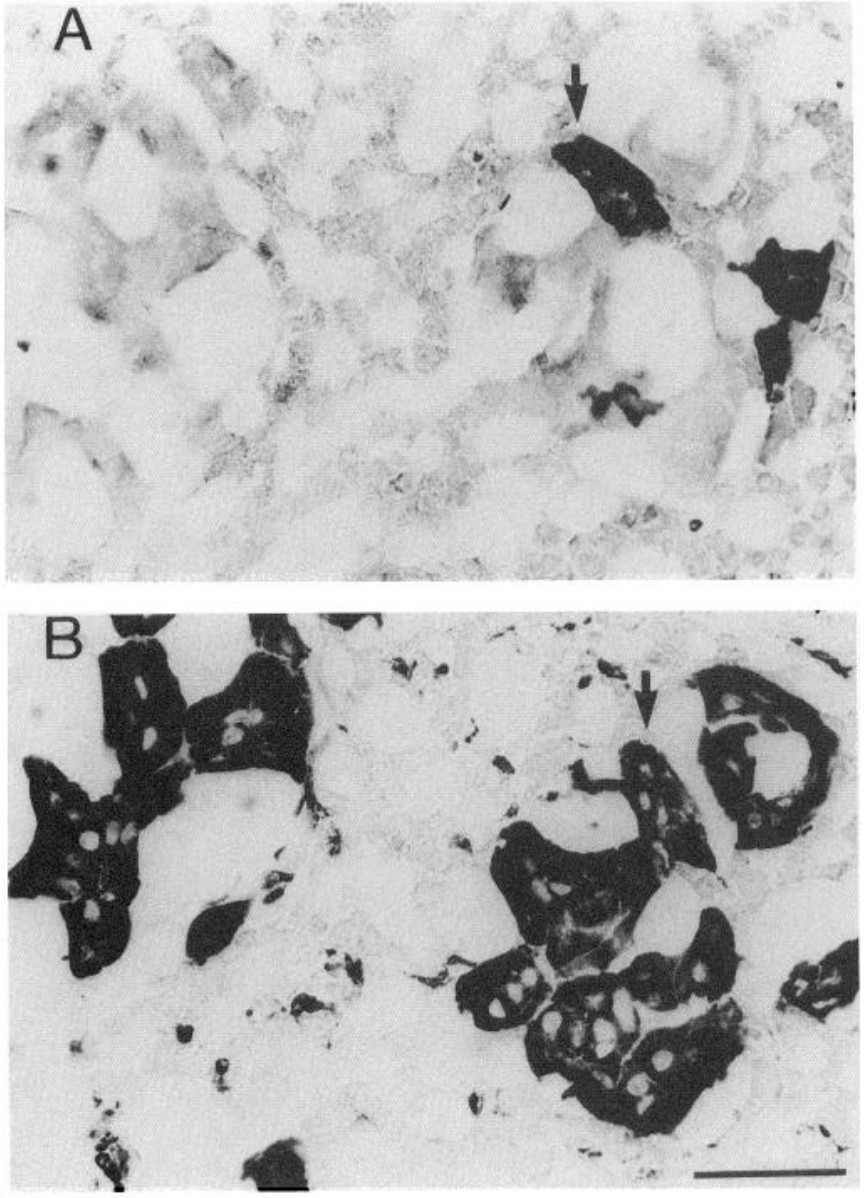

Figure 2. Expression of vesicular monoamine transporters in the adrenal gland. Consecutive sections cut through the adrenal medulla show several cells immunoreactive for VMAT2 $(A)$ and numerous cells immunoreactive for VMAT1 $(B)$. Sections through the adrenal medulla showed that all chromaffin cells stain for VMAT1 and preadsorption of the antibody with the peptide immunogen blocks this staining (data not shown). In contrast, only occasional chromaffin cells immunostain for VMAT2. Nonetheless, these cells had the morphology typical of adrenal chromaffin cells and not of sympathetic ganglion neurons or adrenal cortical cells. Scale bar, $100 \mu \mathrm{m}$.

munoreactive cells have the typical morphology of chromaffin cells, and do not have the large cell body and processes characteristic of ganglion cells. However, since we did not observe ganglion cell staining with either antibody, the results do not exclude expression of VMAT2 by ganglion cells but rather indicate that the majority of VMAT2-immunoreactive cells in the adrenal gland are chromaffin cells.

\section{PNS}

Sympathetic nervous system. Similar to adrenal chromaffin cells, sympathetic ganglion cells also derive from the neural crest and express monoamine transmitters. By immunocytochemistry, sympathetic ganglion cells do not express VMAT1. In contrast, we detect VMAT2-immunoreactive processes in all peripheral tissues evaluated in this study. Figure $3 B$ shows VMAT2-immunoreactive small diameter fibers and varicosities that are typical of sympathetic nerves in the submandibular gland. Figure $4 C$ shows the VMAT2-immunoreactive innervation of blood vessels which is likely to be derived from sympathetic ganglion cells. We also evaluated the superior cervical ganglion. Ganglion 

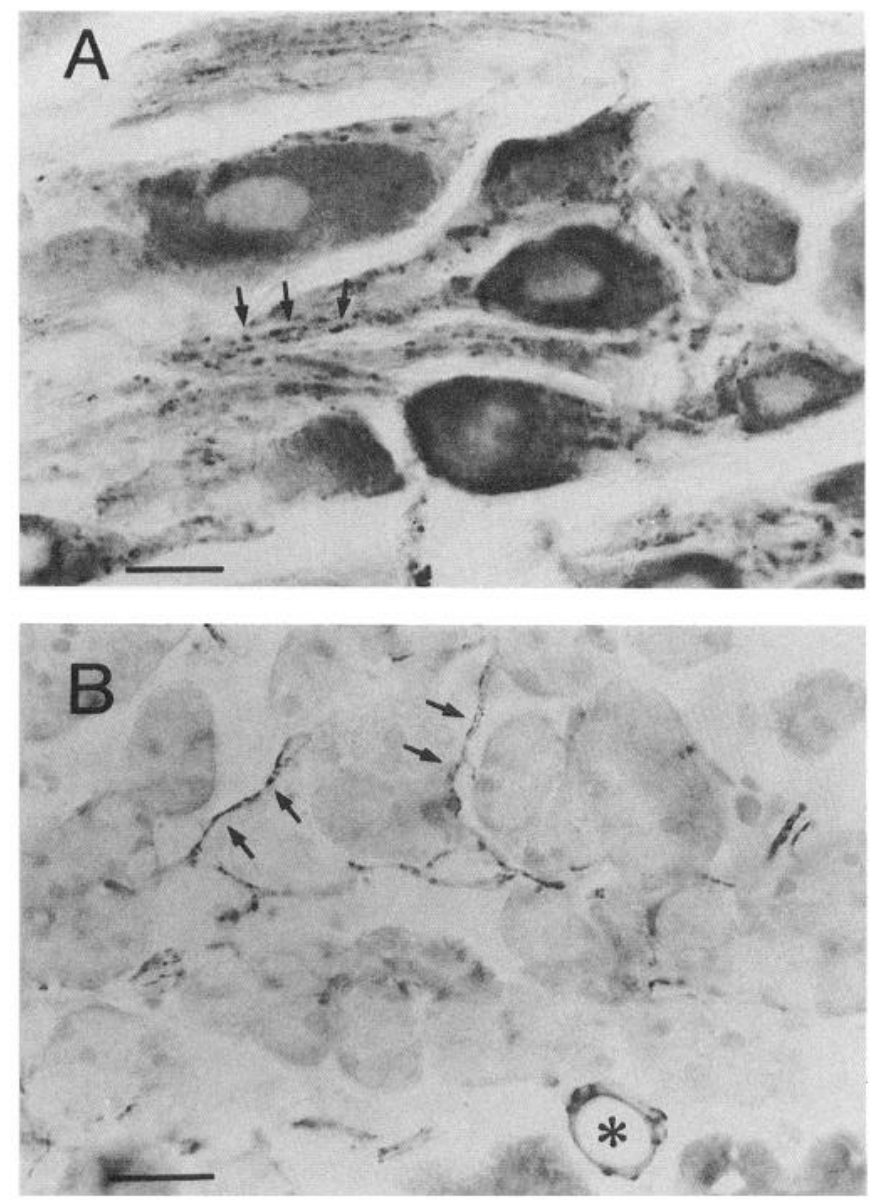

Figure 3. Expression of VMAT2 in the PNS. A, VMAT2-immunoreactive cell bodies and thin, varicose processes (arrows) occur in the superior cervical ganglion. $B$, VMAT-2 immunoreactive processes surround acini (arrows) and a small blood vessel (asterisk) in the submandibular gland. Scale bars: $A, 15 \mu \mathrm{m} ; B, 25 \mu \mathrm{m}$. cells show no detectable reaction for VMAT1, but strong reaction for VMAT2 (Fig. 3A), consistent with the VMAT2-immunoreactive staining of peripheral processes. Thus, postganglionic sympathetic neurons differ from adrenal chromaffin cells in the expression of vesicular amine transporters.

Gastrointestinal tract. Dense networks of VMAT2-immunoreactive fibers innervate the blood vessels (Fig. 4C). VMAT2 immunoreactivity is also found in the dense, varicose processes of the enteric plexuses and interconnecting strands (Fig. 4A) and in some intrinsic neurons. Furthermore, a large number of gastric mucosal cells in the fundus and corpus are VMAT2-immunoreactive (Fig. 4B). These cells are probably enterochromaffinlike (ECL) cells as indicated by their location and morphology. Consistent with previous work showing that VMAT2 has approximately two orders of magnitude higher affinity for histamine than VMAT1 (Peter et al., 1994), these histamine-containing cells in the stomach express VMAT2 (Fig. 4B). Preadsorption of the VMAT2 antiserum with the peptide used to generate it also eliminated the staining (Fig. 4D), further demonstrating the specificity of the immunoreaction for this vesicular amine transporter. In contrast, we did not detect any expression of VMAT1 by enteric neurons, although occasional endocrine cells in the gastrointestinal did immunostain for VMAT1 (data not shown).

\section{CNS}

All monoamine cell groups in the central nervous system express VMAT2 immunoreactivity and their processes are distributed along the entire neuraxis. The dopamine cells including those in the dorsal premammillary nucleus, substantia nigra, pars compacta and ventral tegmental area contain VMAT2 (Fig. 5). Norepinephrine cell groups including A5, the locus coeruleus and subcoeruleus also express VMAT2 (Fig. 6). Adjacent sections stained with an antibody to tyrosine hydroxylase showed the identical pattern of immunoreactivity in these dopaminergic and noradrenergic populations (data not shown). The serotoner-
Figure 4. Expression of VMAT2 in the gastrointestinal tract. $A$, VMAT2-immunoreactive varicose processes in the myenteric plexus and interconnecting strands in the ileum. $B$, VMAT2-immunoreactive enterochromaffin-like cells appear at the base of the gastric mucosa. $C$, A dense network of VMAT2-containing processes innervate a blood vessel in the submucosa of the ileum. $D$, Preadsorption with an excess of VMAT2 peptide used to generate the antibody completely abolishes the immunoreactivity in the submucosa of the ileum. Scale bar, 25 $\mu \mathrm{m}$.
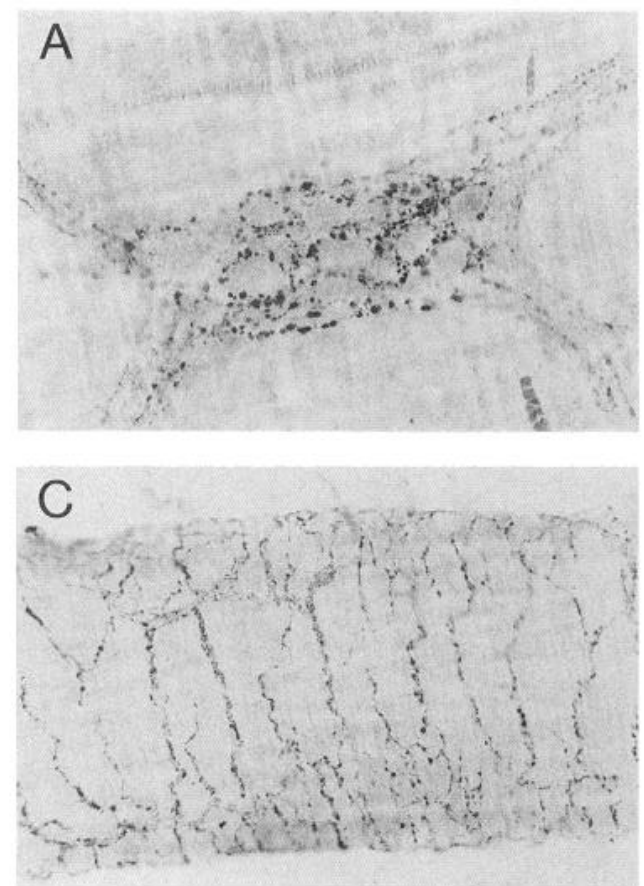
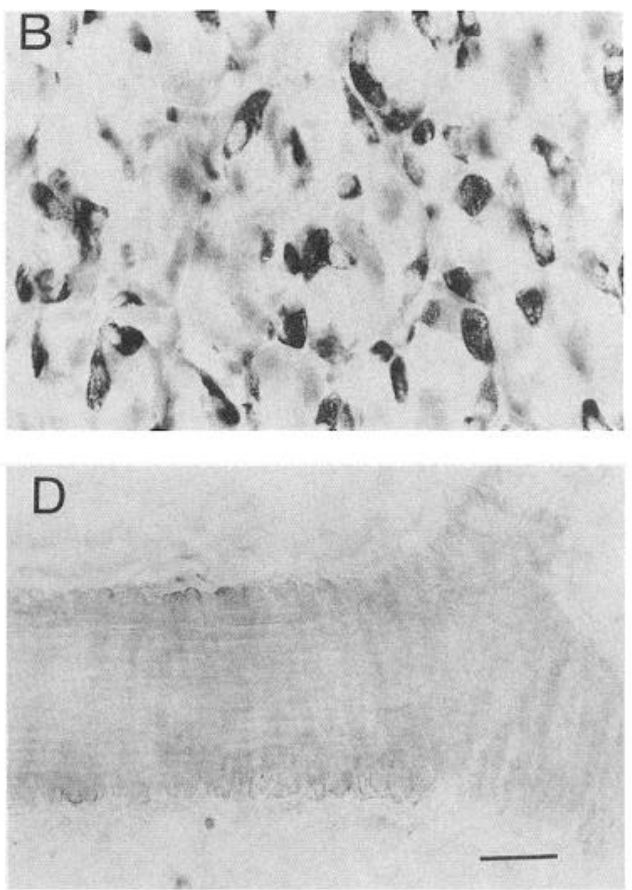

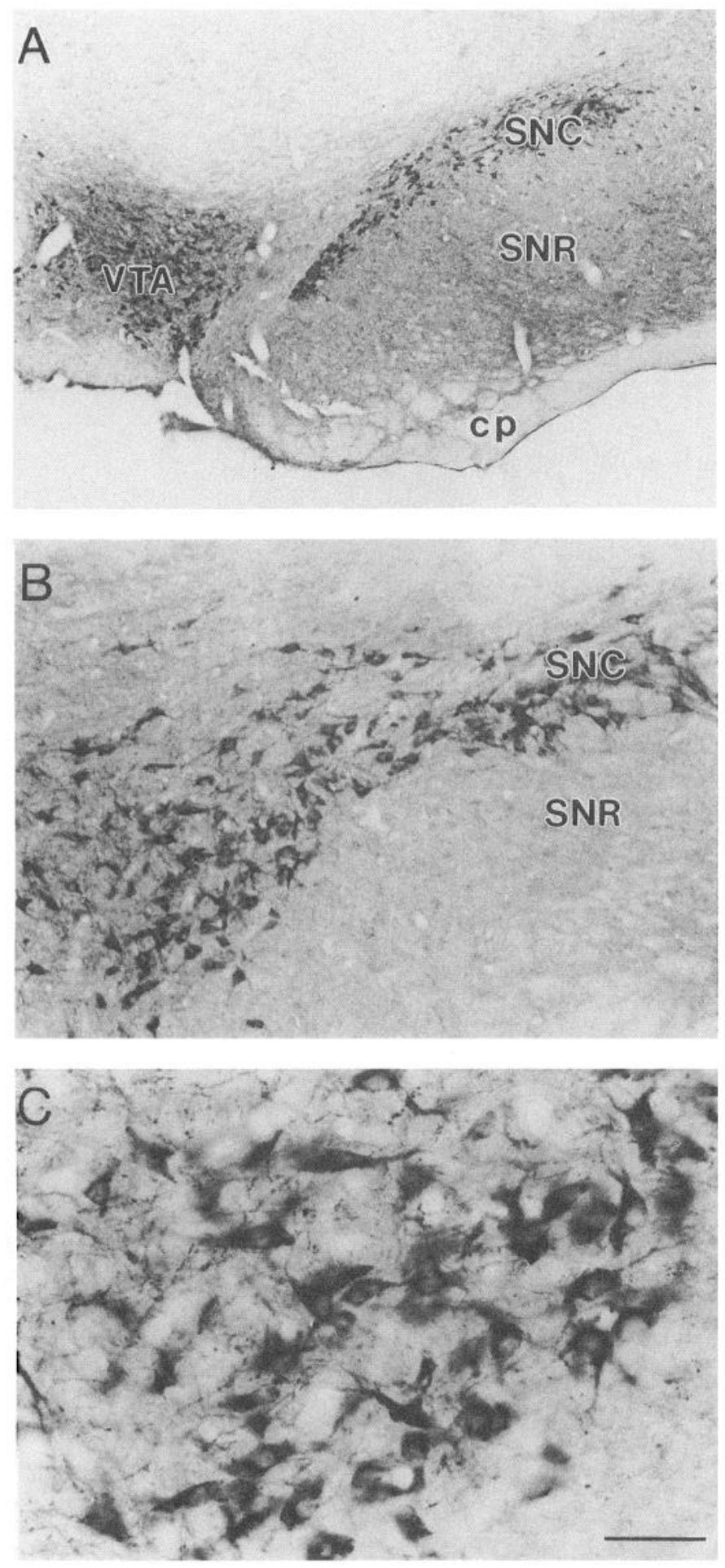

Figure 5. VMAT2 immunoreactivity in dopamine cell groups of the midbrain. $A$, Neurons in the substantia nigra, pars compacta $(S N C)$ and ventral tegmental area (VTA) both stain strongly for VMAT2. Substantia nigra, pars reticulata $(S N R)$ shows little immunoreactivity. $B$ and $C$, VMAT2-immunoreactive neurons in the SNC show strong staining of cell bodies but weaker staining in dendrites. $c p$, Cerebral peduncle. Scale bar: $A, 50 \mu \mathrm{m} ; B, 100 \mu \mathrm{m} ; C, 300 \mu \mathrm{m}$.
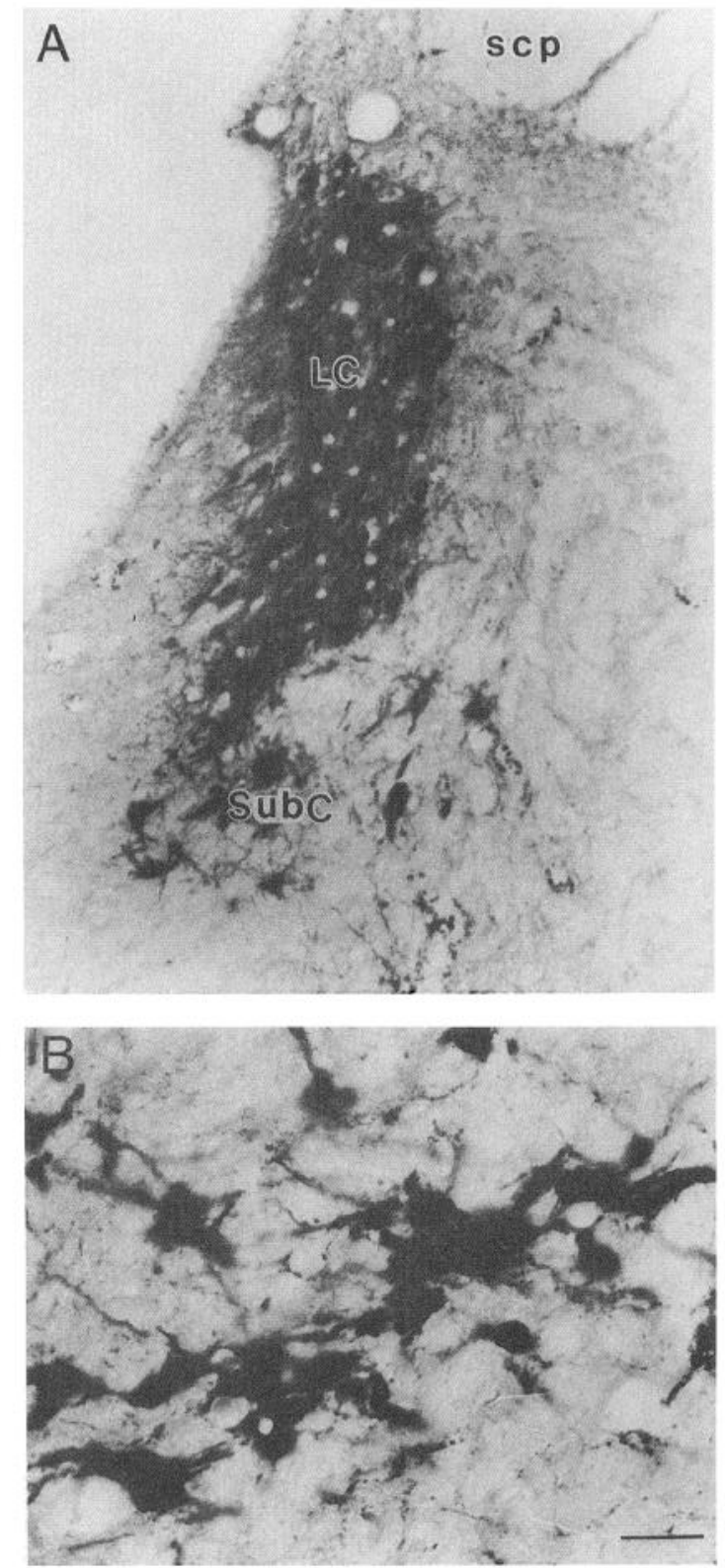

Figure 6. VMAT2 immunoreactivity in norepinephrine cell groups. A, Immunoreactive cell bodies and processes in the locus coeruleus $(L C)$ and subcoeruleus $(s u b C)$. B, VMAT2-immunoreactive neurons in the A5 cell group located in the ventrolateral pons. $s c p$, Superior cerebellar peduncle. Scale bar: $A, 150 \mu \mathrm{m} ; B, 300 \mu \mathrm{m}$.

gic cell groups including the dorsal and median raphe and the raphe pallidus also contain VMAT2-immunoreactive cells (Figs. 7, 8). Adjacent sections stained with an antibody to 5-HT showed an identical pattern of immunoreactivity in these cell groups (data not shown). Finally, epinephrine cell populations such as the $\mathrm{Cl}$ group also express VMAT2. In addition, the antiserum recognizes monoamine-containing fibers including the medial forebrain bundle, the dorsal catecholamine bundle and central tegmental tract.

Dopamine cell groups. Cells in the substantia nigra, pars compacta show much greater susceptibility to the neurotoxin MPTP and to idiopathic Parkinson's disease than other dopamine populations (Langston et al., 1983). Immunocytochemistry shows strong staining for VMAT2 in both the substantia nigra and the 


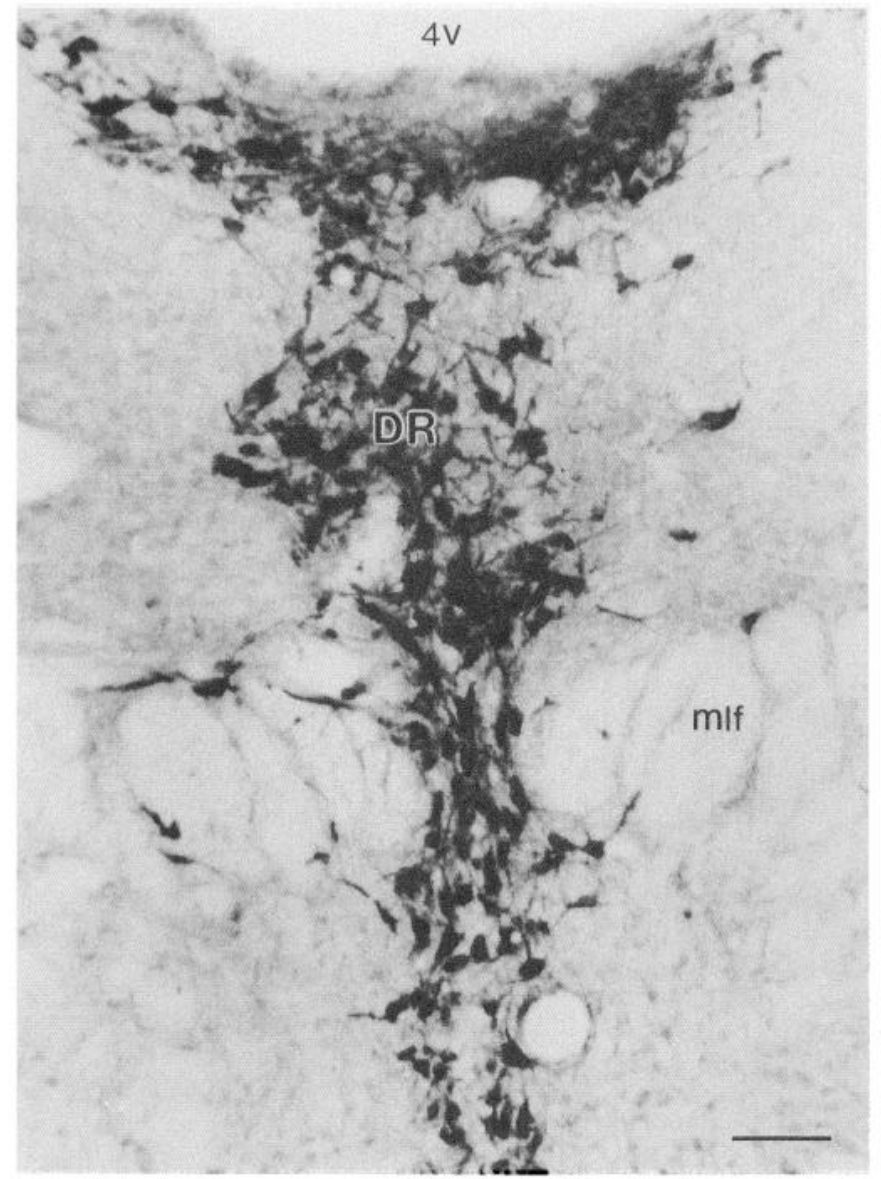

Figure 7. VMAT2 immunoreactivity in the serotonergic dorsal raphe nucleus $(D R) . m l f$, medial longitudinal fasciculus; $4 v$, fourth ventricle. Scale bar, $100 \mu \mathrm{m}$.

ventral tegmental area (Fig. 5A). The relatively MPTP-resistant dopamine groups such as those in the hypothalamus as well as dorsal midbrain also immunostain for VMAT2. VMAT2 immunoreactivity is present in the cytoplasm and localized most heavily to the soma, proximal dendrites and axonal processes (Fig. 5B,C). The pattern of staining differs from the more diffuse cytoplasmic pattern observed with tyrosine hydroxylase that includes a larger proportion of the dendrites (data not shown).

Noradrenaline, 5-HT, and histamine cell groups. Cell bodies and processes in the noradrenergic locus coeruleus and subcoeruleus immunostain strongly for VMAT2 (Fig. 6A). In addition, the norepinephrine cell group A5 expresses VMAT2 (Fig. 6B). Serotonergic groups including the dorsal raphe, median raphe, and raphe pallidus nuclei also stain strongly for VMAT2 (Figs. $7,8)$. We find that histamine-containing neurons in the posterior hypothalamus express VMAT2 (Fig. 9). Epinephrine cells are also likely to stain for VMAT2 (data not shown). For example, cells in the solitary nucleus known to express phenylethanolamine- $N$-methyltransferase (PNMT) (Ruggiero et al., 1994) are in the same position as cells expressing VMAT2. In contrast, we detected no immunoreactivity for VMAT1 in the brain (data not shown).

Olfactory bulb. The olfactory bulb contains a large number of dopaminergic neurons in the glomerular layer (Halasz et al., 1977). Earlier in situ hybridization studies had shown no VMAT1 or VMAT2 mRNA-containing cells (Liu et al., 1992b).

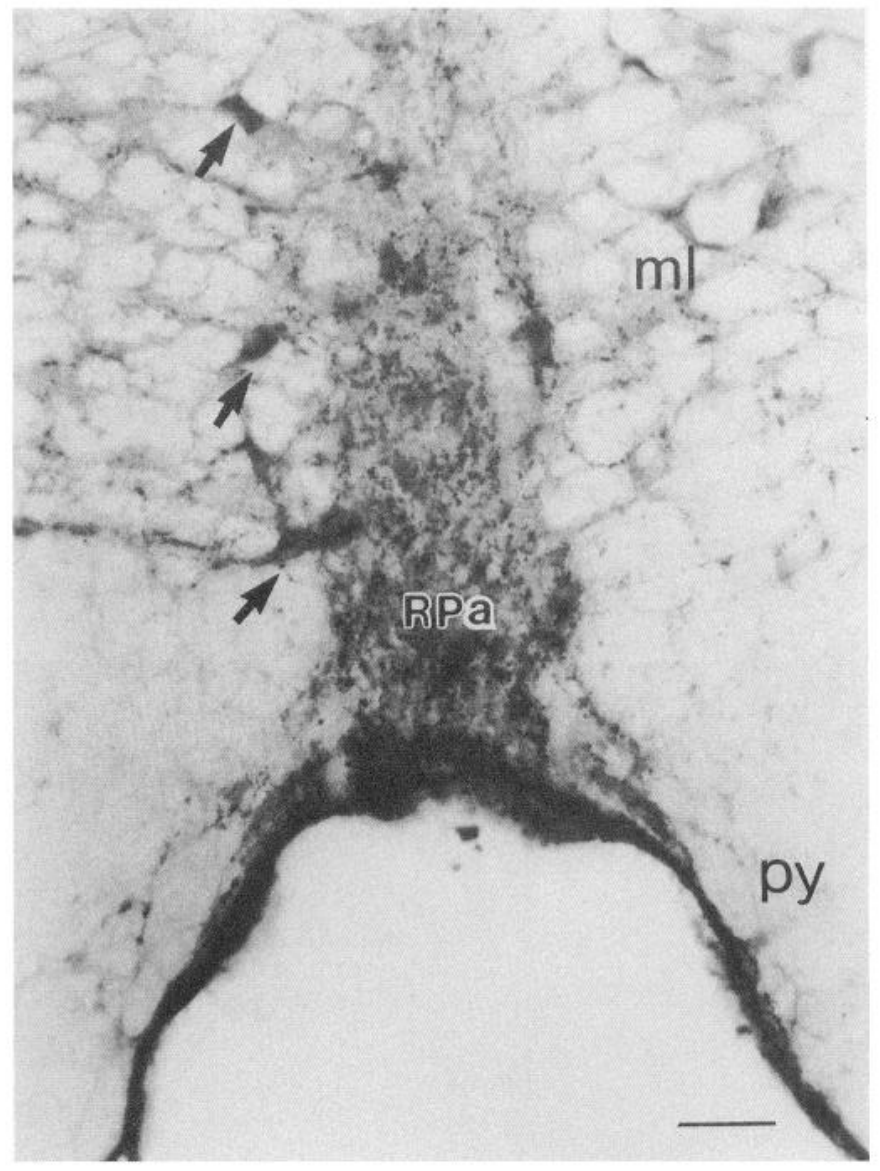

Figure 8. VMAT2 immunoreactivity in the serotonergic nucleus raphe pallidus $(R P a)$. Arrows indicate VMAT2-immunoreactive cell bodies. $\mathrm{ml}$, Medial lemniscus; py, pyramidal tract. Scale bar, $300 \mu \mathrm{m}$.

Immunocytochemical studies also fail to demonstrate either VMAT1 or VMAT2 immunoreactivity in the olfactory bulb (data not shown). Indeed, we have screened a cDNA library prepared from the olfactory bulb with both cDNAs and found no positively hybridizing signal. As interneurons, these cells may express lower levels of transporter than projection neurons in the brainstem. However, we have detected VMAT2 mRNA and VMAT2 immunoreactivity in other interneuron populations such as the retina (data not shown).

Terminal fields. Since localization of the vesicular amine transporters determines the site of storage, it was thus of particular interest to examine the immunoreactivity of VMAT2 in terminal fields. Axonal fibers containing VMAT2 were present along the entire neuraxis. For example, the cortex contains small immunoreactive fibers with periodic varicosities (Fig. 10A). In the basal ganglia, the projections are very fine and frequently difficult to discern as discrete processes (Fig. 10B). As noted above, the dendrites of substantia nigra neurons stain for VMAT2 but at reduced levels compared to cell bodies (Fig. 5C). On the other hand, dendrites of neurons in the locus coeruleus and dorsal raphe stain strongly for VMAT2 (Figs. 6, 7). Neuropil in the ventromedial hypothalamus stain particularly strongly (Fig. 10C).

\section{Discussion}

The antibodies that we have raised appear specific for VMAT1 and VMAT2. The peptides used to generate them derive from 

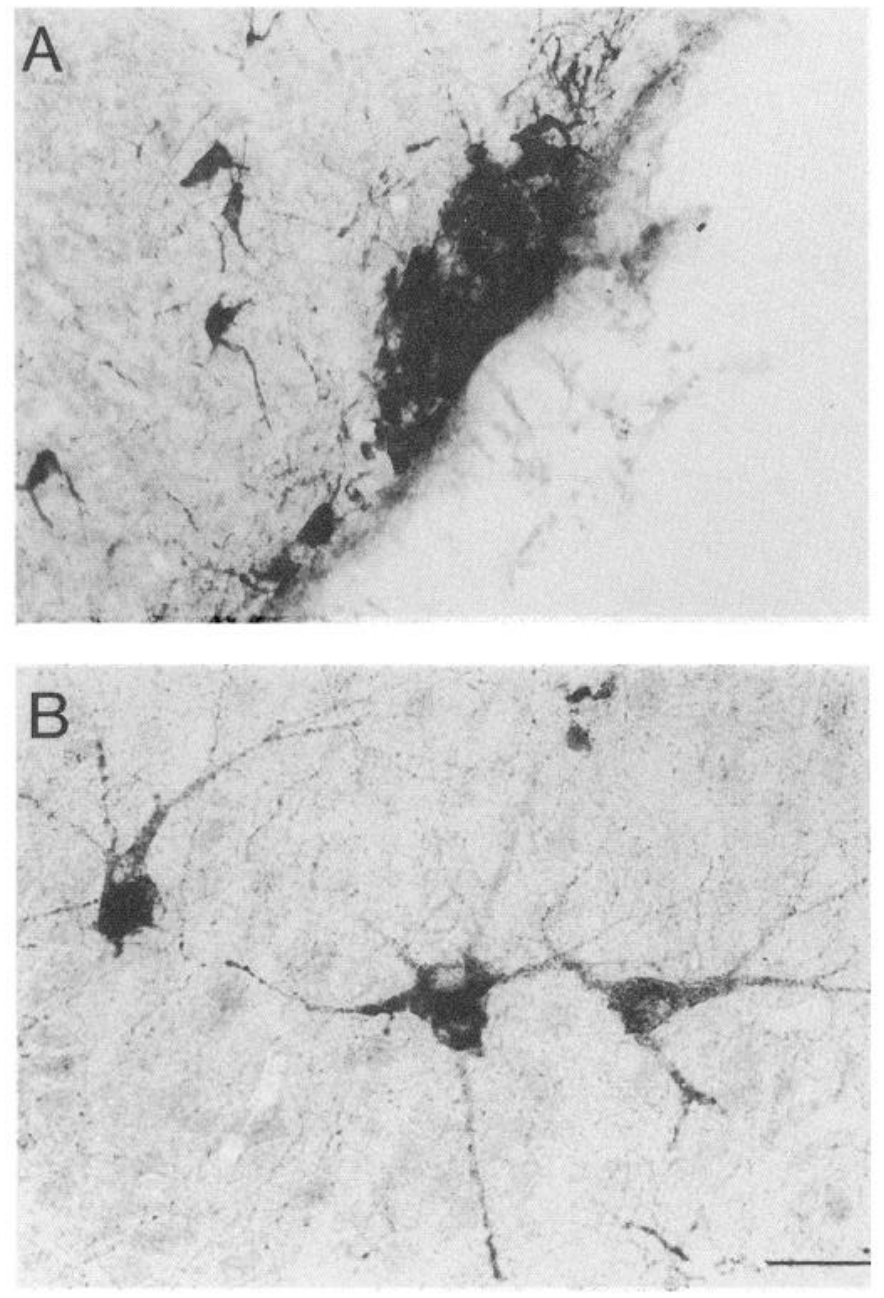

Figure 9. Histamine cell groups in the posterior hypothalamus stain for VMAT2. Histamine-containing E2 $(A)$ and E5 $(B)$ subgroups react with the VMAT2 but not VMAT1 antibody (data not shown). Scale bar: $A, 120 \mu \mathrm{m} ; B, 300 \mu \mathrm{m}$.

divergent regions at the $\mathrm{C}$-terminus of the two transporters. The antisera detect VMAT1 in the adrenal medulla and VMAT2 in known monoamine cell groups in the nervous system. Further, the VMAT1 antibody does not recognize VMAT2-immunoreactive populations in the brain and the VMAT2 antibody does not recognize VMAT1 on Western blots.

We have previously identified VMAT1 immunoreactivity in chromaffin cells of the adrenal medulla (Liu et al., 1994). Although we could not detect mRNA transcripts for VMAT2 in extracts of the adrenal gland, immunocytochemistry shows scattered immunoreactive cells. The low proportion of positive cells presumably accounts for the undetectable level of VMAT2 transcripts on Northern blots. Mahata et al. (1993) also report VMAT2 transcripts in the adrenal gland by in situ hybridization with oligonucleotide probes. However, they describe grains over what appear to be ganglion cells rather than chromaffin cells. Although we did not observe ganglion cell staining with either antibody and cannot therefore exclude expression of VMAT2 by ganglion cells, immunocytochemistry clearly indicates expression of VMAT2 by clusters of cells in the medulla which have the size and morphology typical of chromaffin cells, not ganglion cells. Further, ganglion cells in the rat express AChE and not catecholamine biosynthetic enzymes (Schalling et al., 1988), suggesting a cholinergic rather than aminergic phenotype.

Sympathetic ganglion cells express VMAT2. Immunostaining reveals expression in both peripheral processes and cell bodies in the ganglion. Similarly, some enteric neurons in the digestive tract express VMAT2 immunoreactivity. Thus, although adrenal chromaffin cells, postganglionic sympathetic neurons and the enteric nervous system derive from the neural crest, they express distinct vesicular amine transporters. Since all chromaffin cells stain for VMAT1, the clusters of VMAT2-immunoreactive chromaffin cells in the adrenal medulla suggest that both transporters are expressed in the same cells and may therefore represent either an intermediate in the pathway of differentiation or an intermediate mature phenotype. The expression of both VMAT1 and VMAT2 by some chromaffin cells in the adrenal medulla raises the possibility that steroids derived from the adrenal cortex may influence their phenotype. However, glucocorticoids activate differentiation toward the chromaffin cell and away from the sympathetic ganglion cell pathway (Anderson, 1993). Alternatively, other environmental cues perhaps derived from the adrenal cortex may influence the differentiation of these cells. In any case, the two vesicular amine transporters provide useful, additional markers for the alternative fates of differentiation into chromaffin cells versus ganglion cells.

Expression of VMAT1 and VMAT2 in the adrenal gland of the rat appears to differ from expression in the adrenal gland of cattle. Using bovine chromaffin cells as a source, Schuldiner and colleagues purified a vesicular amine transporter with the high sensitivity to tetrabenazine which is suggestive of VMAT2 (Stern-Bach et al., 1990). N-Terminal peptide sequence analysis followed by cDNA cloning showed a closer relationship of this transporter to rat VMAT2 than rat VMAT1 (Stern-Bach et al., 1992; Krejci et al., 1993; Howell et al., 1994). Interestingly, purification had yielded two proteins differing in their isoelectric points. Molecular cloning has shown the existence of bovine VMAT1 (Gasnier et al., 1994) as well as bovine VMAT2, raising the possibility that the two isoforms represent VMAT1 and VMAT2. In any case, the ability to purify VMAT2 from the bovine adrenal medulla clearly indicates that VMAT2 constitutes a large proportion of the total vesicular amine transporters in this tissue. The miniscule amount of VMAT2 present in the rat adrenal suggests that the relative expression of the two transporters in the adrenal gland would vary considerably in different species and raises the possibility that varying proportions of VMAT1 and VMAT2 confer physiologically significant differences in function.

The expression of VMAT1 by adrenal chromaffin cells and VMAT2 by ganglion cells has implications for the release and turnover of monoamines by these two cell populations. VMAT1 has a lower affinity than VMAT2 for most monoamine substrates and also has a lower turnover number (Peter et al., 1994). Thus, VMAT2 is more adapted to the rapidly recycling synaptic vesicles at sympathetic nerve terminals whereas VMAT1 may function adequately to fill the slowly recycling dense core vesicles in chromaffin cells. In addition, the transporters differ in pharmacology. Reserpine potently inhibits both VMAT1 and VMAT2 but tetrabenazine inhibits VMAT2 much more potently than VMAT1. Interestingly, reserpine depletes both central and peripheral monoamine stores whereas tetrabenazine has been known to have a more selective central effect (Carlsson, 1965). This may in turn account for the reduced side-effect of hypotension observed with tetrabenazine as opposed to reserpine 

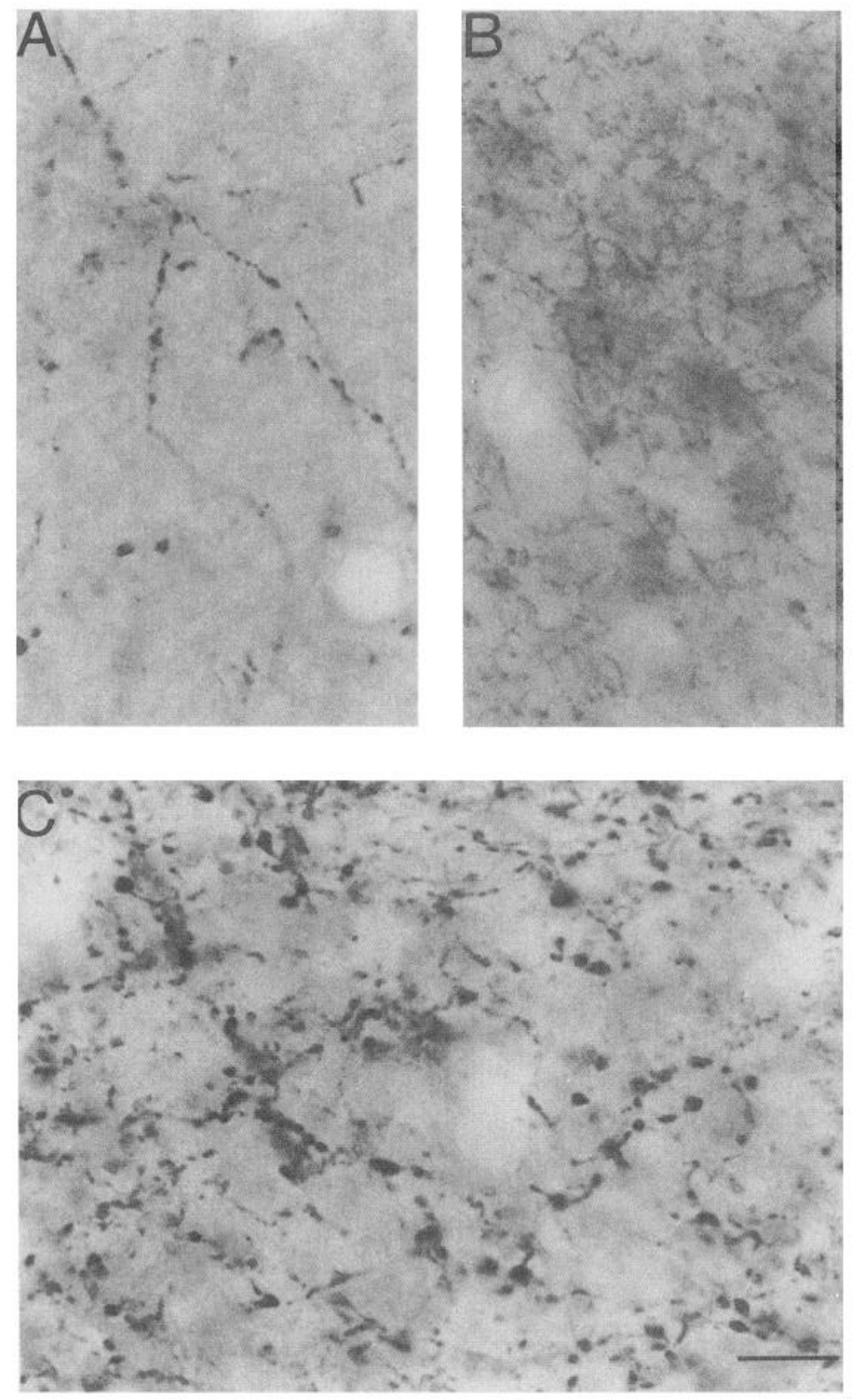

Figure 10. VMAT2 immunoreactivity in terminal fields. Monoamine projections in the cortex $(A)$, caudate $(B)$ and ventromedial hypothalamus $(C)$ stain for VMAT2. Scale bar: $A, 50 \mu \mathrm{m}$; $B, 100 \mu \mathrm{m} ; C, 300 \mu \mathrm{m}$.
(Jankovic and Orman, 1988). Although the precise sites at which reserpine acts to reduce blood pressure remain uncertain, the clinically reduced hypotensive properties of tetrabenazine in combination with the known differences in pharmacology between VMAT1 and VMAT2 suggest that the adrenal medulla also contributes significantly to the regulation of blood pressure.

The anatomic distribution of VMAT1 and VMAT2 also coincides with known differences in substrate preference. The enterochromaffin-like cells in the stomach and histamine-containing neurons in the hypothalamus express VMAT2, and VMAT2 has an affinity for histamine in the range of the affinity for other monoamines whereas VMAT1 has a relatively poor affinity for histamine (Peter et al., 1994). In addition, central nervous system monoamine cells express VMAT2 rather than VMAT1. The twoto threefold higher affinity of VMAT2 than VMAT1 for most monoamine substrates (Peter et al., 1994) may be required for the more rapid turnover of monoamines released from synaptic vesicles rather than from chromaffin granules. Alternatively, VMAT2 may undergo more complex regulation than VMAT1, either at the transcriptional level or at the posttranslational level as a result of additional potential phosphorylation sites (Erickson et al., 1992; Liu et al., 1992b). VMAT2 may also contain signals that sort the protein to synaptic vesicles as opposed to the signals that sort VMAT1 to dense core vesicles in chromaffin cells (Liu et al., 1994).

The pattern of VMAT2 expression in the CNS does not correlate with vulnerability to MPTP toxicity and idiopathic Parkinson's disease. Immunocytochemistry does not provide quantitation, but both vulnerable populations such as large dopaminergic neurons in the substantia nigra, pars compacta and resistant monoamine populations such as noradrenergic neurons in the locus coeruleus and serotonergic neurons in the raphe nuclei express high levels of VMAT2 in the cell body. Thus, reduced VMAT2 expression does not appear to account for differential susceptibility. Rather, the robust expression of VMAT2 by dopaminergic neurons in the substantia nigra remains insufficient to protect neurons in the substantia nigra.

Curiously, periglomerular neurons in the olfactory bulb that 
contain dopamine do not appear to express either VMAT1 or VMAT2. In situ hybridization showed no signal using either cDNA as probe but low levels of expression by this population of interneurons could make detection difficult. Both antibodies show no immunoreactivity and screening $>10^{6}$ clones of an olfactory bulb library yielded none hybridizing with either VMAT1 or VMAT2 even at reduced stringency. Thus, periglomerular interneurons in the olfactory bulb either express extremely low levels of a vesicular amine transporter (perhaps consistent with their reduced terminal fields), an unrelated transporter or no vesicular amine transport at all. In the absence of vesicular amine transport activity, the regulated release of monoamines could involve reversal of plasma membrane transporters. The depolarization of electrogenic plasma membrane transporters for GABA and glutamate can produce the regulated but $\mathrm{Ca}^{++}$-independent, nonvesicular release of transmitter (Schwartz, 1987; Attwell et al., 1993). This may also occur with a plasma membrane dopamine transporter (Sulzer et al., 1993) that, in contrast to VMAT2, has been shown to exist in dopaminergic neurons including those of the olfactory bulb (Cerruti et al., 1993). Periglomerular intrinsic neurons dopamine do contain synaptic vesicles but relatively few and these may store the coexpressed GABA rather than dopamine (Pinching and Powell, 1971a-c; Mugnaini et al., 1984). In contrast to other monoamine populations, reduced expression of vesicular amine transport by olfactory bulb interneurons may account for their apparent vulnerability in Parkinson's disease. Reduced olfactory sensation has even been suggested as an early marker of the disease (Daniel and Hawkes, 1992; Doty et al., 1992; Stern et al., 1994).

In addition to the level of vesicular amine transport activity, the subcellular location of the vesicular transporters will also influence the ability to protect against either an exogenous toxin such as MPTP or an endogenous toxin such as dopamine. In the case of $\mathrm{MPP}^{+}$, vesicular amine transport can limit access of the toxin to mitochondria. In the case of dopamine, vesicular amine transport close to the site of synthesis or reuptake could reduce the potential for cytoplasmic oxidation of the transmitter and also protect the cell. Innmunostaining shows expression of VMAT2 in both dendrites and nerve terminals. However, in contrast to tyrosine hydroxylase immunoreactivity which occurs densely throughout the cytoplasm of pars compacta cells, VMAT2 immunoreactivity is considerably stronger in the cell body than the dendrites, particularly in the more distal parts. This presumably reflects the more limited distribution of intracellular vesicles expressing VMAT2 whereas tyrosine hydroxylase diffuses more freely throughout the cytoplasm. It follows therefore that reduced expression of the transporter in dendrites could render this part of the neuron more vulnerable. Interestingly, the dendrites of other monoamine populations in the locus coeruleus and raphe appear to stain more intensely than those in the substantia nigra, possibly accounting for their resistance to degeneration. The expression of VMAT2 in dendrites also indicates the potential for monoamine release at this site, which may serve to modulate presynaptic input (Cherany et al., 1981).

The regulated release of transmitter in the nervous system generally occurs through the fusion of specialized vesicles with the plasma membrane. In contrast to small, clear synaptic vesicles that store classical transmitters such as $\mathrm{ACh}$ and glutamate, large dense core vesicles (or secretory granules in endocrine cells) store neural peptides (de Camilli and Jahn, 1990; Trimble et al., 1991; Kelly, 1993). Synaptic vesicles cluster over the nerve terminal and mediate the rapid release of transmitter whereas dense core vesicles also occur in dendrites and release more slowly. Monoamines differ from other classical transmitters and also appear in dense core granules in the adrenal gland (Johnson, 1988). However, classical studies using 5-OH-dopamine as an osmiophilic false transmitter recognized by the amine transporters have suggested the storage of monoamines in smaller vesicles in the brain (Smith, 1972; Thureson-Klein, 1983; Pellegrino de Iraldi, 1992). Since localization of the vesicular amine transporter determines the site of amine storage and hence the site and mode of amine release, it is of considerable interest to determine the location of the transporter in central neurons. In addition to its presence on somata and dendrites, VMAT2 also occurs throughout the axon and nerve terminals. For example, axonal processes were clearly seen surrounding blood vesscls in the periphery as well as distributed through the basal ganglia and cortex in the brain. Indeed, VMAT2-immunoreactive fibers are seen in all regions known to contain monoamine processes. It will now be of particular interest to determine the nature of the vesicles (e.g., synaptic vesicles or dense core vesicles) expressing VMAT2 in cortical and striatal projections as well as dendrites.

In conclusion, we have raised antibodies specific for the two vesicular monoamine transporters and used these to demonstrate the distribution of the proteins in vivo. We have detected VMAT1 in the adrenal medulla but not in neural cells. VMAT2 occurs in enteric neurons, sympathetic ganglia and central monoamine populations, with high levels expressed by dopaminergic neurons in the substantia nigra. The more rapid turnover of synaptic vesicles in neurons as opposed to chromaffin cells may require the higher affinity and faster turnover of VMAT2 rather than VMAT1. Interestingly, a relatively small number of cells in the adrenal medulla appear to express both transporters and dopaminergic neurons of the olfactory bulb do not appear to express either VMAT1 or VMAT2, raising questions about the mode of dopamine release by these cells. In terms of subcellular distribution within neurons, VMAT2 occurs in the cell body and terminal processes but the dendrites show staining relatively restricted to the proximal segments.

\section{References}

Amara SG, Kuhar MJ (1993) Neurotransmitter transporters: recent progress. Annu Rev Neurosci 16:73-93.

Anderson DJ (1993) Molecular control of cell fate in the neural crest. Ann Rev Neurosci 16:129-158.

Attwell D, Barbour B, Szatkowski M (1993) Nonvesicular relcasc of neurotransmitter. Neuron 11:401-407.

Carlsson A (1965) Drugs which block the storage of 5-hydroxytryptamine and related amines. Handb Exp Pharmacol 19:529-592.

Cerruti C, Walther DM, Kuhar MJ, Uhl GR (1993) Dopamine transporter mRNA expression is intense in rat midbrain neurons and modest outside midbrain. Brain Res Mol Brain Res 18:181-186.

Cheramy A, Leviel V, Glowinski J (1981) Dendritic release of dopamine in the substantia nigra. Nature 289:537-542.

Cubells JF, Rayport S, Rajendran G, Sulzer D (1994) Methamphetamine neurotoxicity involves vacuolation of endocytic organells and dopamine-dependent intracellular oxidative stress. J Neurosci 14: $2260-2271$.

Daniel SE, Hawkes CH (1992) Preliminary diagnosis of Parkinson's disease by olfactory bulb pathology. Lancet 340:186.

De Camilli P, Jahn R (1990) Pathways to regulated exocytosis in neurons. Annu Rev Physiol 52:625-645.

Del Zompo M, Piccardi MP, Ruiu S, Quartu M, Gessa GL, Vaccari A (1993) Selective MPP+ uptake into synaptic dopamine vesicles: possible involvement in MPTP neurotoxicity. Br J Pharmacol 109:411414.

Doty RL, Stern MB, Pfeifer C, Gollomp SM, Hurtig HI (1992) Bilat- 
eral olfactory dysfunction in early stage treated and untreated idiopathic Parkinson's disease. J Neurol Neurosurg Psychol 55:138-142.

Edwards RH (1992) The transport of neurotransmitters into synaptic vesicles. Curr Opin Neurobiol 2:586-594.

Erickson JD, Eiden LE, Hoffman BJ (1992) Expression cloning of a reserpine-sensitive vesicular monoamine transporter. Proc Natl Acad Sci USA 89:10993 10997

Fishkes H, Rudnick G (1982) Bioenergetics of serotonin transport by membrane vesicles derived from platelet dense granules. J Biol Chem 257:5671-5677.

Gasnier B, Krejci E, Botton D, Massoulie J, Henry J P (1994) Expression of a bovine vesicular monoamine transporter in COS cells. $342: 225-229$.

Howell M, Shirvan A, Stern-Bach Y, Steiner-Mordoch S, Strasser JE, Dean GE, Schuldiner S (1994) Cloning and functional expression of a tetrabenazine sensitive vesicular monoamine transporter from bovine chromaffin granules. FEBS Lett 338:16-22.

Jankovic J, Orman J (1988) Tetrabenazine therapy of dystonia, chorea, tics, and other dyskinesias. Neurology 38:391-394.

Javitch J, D'Amato R, Nye J, Javitch J (1985) Parkinsonism-inducing neurotoxin, $\mathrm{N}$-methyl-4-phenyl-1,2,3,6-telrahydropyridine: uplake of the metabolite N-methyl-4-phenylpyridine by dopamine neurons explains selective toxicity. Proc Natl Acad Sci USA 82:2173-2177.

Kelly RB (1993) Storage and release of neurotransmitters. Cell 72:4353.

Krejci E, Gasnier B, Botton D, Isambert MF, Sagne C, Gagnon J, Massoulie J, Henry JP (1993) Expression and regulation of the bovine vesicular monoamine transporter gene. FEBS Lett 335:27-32.

Krueger MJ, Singer TP, Casida JE, Ramsay RR (1990) Evidence that the blockade of mitochondrial respiration by the neurotoxin 1-methyl4-phenylpyridinium (MPP + ) involves binding at the same site as the respiratory inhibitor, rotenone. Biochem Biophys Res Commun 169: $123-128$.

Langston JW, Ballard P, Tetrud JW, Irwin I (1983) Chronic parkinsonism in humans due to a product of meperidine analog synthesis. Science 219:979-980.

Liu Y, Roghani A, Edwards RH (1992a) Gene transfer of a reserpinesensitive mechanism of resistance to MPP + . Proc Natl Acad Sci USA 89:9074-9078.

L.ju Y, Peter D, Roghani A, Schuldiner S, Prive GG, Eisenberg D, Brecha N, Edwards RH (1992b) A cDNA that supresses MPP+ toxicity encodes a vesicular amine transporter. Cell 70:539-551.

Liu Y, Schwcitzer ES, Nirenberg MJ, Pickel VM, Evans CJ, Edwards RH (1994) Preferential localization of a vesicular monoamine transporter to dense core vesicles in PC12 cells. J Cell Biol 127.

Mahata SK, Mahata M, Fischer-Colbrie R, Winkler H (1993) Vesicle monoamine transporters 1 and 2: differential distribution and regulation of their mRNAs in chromaffin and ganglion cells of rat adrenal medulla. Neurosci Lett 156:70-72

Michel PP, Hefti F (1990) Toxicity of 6-hydroxydopamine and dopa- mine for dopaminergic neurons in culture. $\mathbf{J}$ Neurosci Res 26:428435.

Mugnaini E, Oertel WH, Wouterlood FF (1984) Immunocytochemical lncalization of GABA neurons and dopamine neurons in the rat main and accessory olfactory bulbs. Neurosci Lett 47:221-226.

Pellegrino de Iraldi A (1992) Compartmentalization of monoaminergic synaptic vesicles in the storage and release of neurotransmitter. Mol Neurobiol 6:323-337.

Peter D, Jimenez J, Liu Y, Kim J, Edwards RH (1994) The chromaffin granule and synaptic vesicle annine transponters dilfer in substrale recognition and sensitivity to inhibitors. J Biol Chem 269:7231-7237.

Pinching AJ, Powell TP (1971a) The neuron types of the glomerular layer of the olfactory bulb. J Cell Sci 9:305-345.

Pinching AJ, Powell TP (1971b) The neuropil of the glomeruli of the olfactory bulb. J Cell Sci 9:347-377.

Pinching AJ, Powell TP (1971c) The neuropil of the periglomerular region of the olfactory buob. J Cell Sci 9:379-409.

Ramsay RR, Singer TP (1986) Energy-dependent uptake of n-methyl4-phenylpyridinium, the neurotoxic metabolite of 1-methyl-4-phenyl1,2,3,6-tetrahydropyridine, by mitochondria. J Biol Chem 261:75857587 .

Rosenberg PA (1988) Catecholamine toxicity in cerebral cortex in dissociated cell culture. J Neurosci 8:2887-2894.

Ruggiero DA, Pickel VM, Milner TA, Anwar M, Otake K, Mtui EP, Park D (1994) Viscerosensory processing in nucleus tractus solitarii structural and neurochemical substrates. In: Nucleus of the solitary tract (Barraco RA, ed), pp 3-34. Boca Raton: CRC.

Schwartz EA (1987) Depolarization without calcium can release gamma-aminobutyric acid from a retinal neuron. Science 238:350-355.

Smith AD (1972) Mechanisms involved in the release of noradrenaline from sympathetic nerve. Br Med Bull 29:123-129.

Stern MB, Doty RL, Dotti M, Corcoran P, Crawford D, McKeown DA, Adler C, Gollomp S, Hurtig H (1994) Olfactory function in Parkinson's disease subtypes. Neurology 44:266-268.

Stern-Bach Y, Greenberg-Ofrath N, Flechner I, Schuldiner S (1990) Identification and purification of a functional amine transporter from bovine chromaffin granules. J Biol Chem 265:3961-3966.

Stern-Bach Y, Keen JN, Bejerano M, Steiner-Mordoch S, Wallach M, Findlay JB, Schuldiner S (1992) Homology of a vesicular amine transporter to a gene conferring resistance to 1-methyl-4-phenylpyridinium. Proc Natl Acad Sci USA 89:9730-9733.

Sudhof TC, Jahn R (1991) Proteins of synaptic vesicles involved in exocytosis and membrane recycling. Neuron 6:665-677.

Sulzer D, Maidment NT, Rayport S (1993) Amphetamine and other weak bases act to promote reverse transport of dopamine in midbrain neurons. J Neurochem 60:527-535.

Thureson-Klein A (1983) Exocytosis from large and small dense cored vesicles in noradrenergic nerve terminals. Neuroscience 10:245-259.

Trimble WS, Linial M, Scheller RH (1991) Cellular and molecular biology of the presynaptic nerve terminal. Annu Rev Neurosci 14: 93-122. 